\title{
Economic Forces Facing the Bank Holding Company Movement
}

\author{
An Address by DARRYL R. FRANCIS, President, Federal Reserve \\ Bank of St. Louis, at the BAI Conference on \\ Bank Holding Company Administration, Chicago, Illinois, August 16, 1974
}

垔

T IS good to have this opportunity to discuss with you some thoughts on the economic forces facing bank holding companies. The bank holding company movement is of increasing interest to both the economic and the political sectors of our society. Bank holding companies own about one-fourth of the nation's barks which, in turn, hold about two-thirds of the banking assets. In addition, they have made substantial inroads in a number of bank-related activities.

Most of the bank holding company growth occurred during the past decade. From 1963 to 1973, the number of multiple bank holding companies rose five-fold, and the number of one-bank holding companies doubled from 1968 to 1973 .

The rapid increase in bank holding companies can be traced to the restrictions on commercial banking. In a competitive market, the type of firm or structure which evolves is that which tends to maximize both profits and consumer well-being. The incentive for proft provides the motivation for banks to fill any voids in their markets. When they observe opportunities to increase services and profits by a change in structure, they will attempt to make such a change.

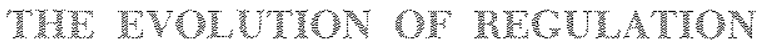

The formation of a bank holding company can be looked upon as a way whereby many restrictions on commercial banks can be overcome and services to the public expanded. In recent years branching restrictions have become increasingly onerous to banks located in declining central cities of unit banking states. Regulation $Q$ has also been more burdensome to banks in the more competitive banking markets with the rising interest rates. Bank holding companies permit banks to expand their operations into new geographic markets through the organization of new firms or through the purchase of existing firms where branches of the parent firm are prohibited. As evidence that holding companies are used to bypass restrictions on individual banks, the multi-bank holding company movement is much more pronounced in unit banking states. For example, in 1972 there was less than 2 multi-bank holding companies per state in the 18 state-wide branching states which permitted multibank holding companies. In contrast, there was 12 per state in the 8 unit banking states which permitted multi-bank holding companies.

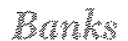

Regulation of banks has proceeded without a clear recognition of what was to be regulated. Most of the restrictions have come about since the early $1930 \mathrm{~s}$ as a result of confusion as to the cause of economic instability.

In the early years of the nation, commercial bank regulation was largely concerned with the chartering provisions for state banks, their bank note (paper 
money) issuing function, and the impact of such issues on the economy. There was little interest in the maintenance of sound banks as long as they could redeem their paper money with specie.

That sage of American politics, Thomas Jefferson, and a number of political leaders who followed, recognized that the restrictions on banking should be directed at the quantity and quality of money rather than other functions of financial frms. Albert Gallatin, Jefferson's Secretary of the Treasury, contended that the creation of bank money should be restrained; but with that single exception, banks should be left free as any other firm. President Jackson in his farewell address in 1837 said that corporations which create paper money cannot be relied on to maintain a uniform amount.

The National Banking Act (1863) focused largely on the quantity and quality of money. A maximum was placed on national bank note issues, and the stock of money (deposits plus notes) was restricted by legal reserve requirements.

While its general focus was on the protection and control of money, the Act contained some provisions for protecting banking firms. It prohibited some banking practices which were considered risky, such as real estate lending. It also provided for a surplus in capital accounts and the examination of all national banks.

The chief objective of examination following the Act was to make sure that the condition of banks would enable them to redeem their notes. In the late 1800s, however, the Comptroller of the Currency adopted the view that the correction of basic managerial difficulties was also a function of bank supervision.

The onginal Federal Reserve Act (1913), while not specifically requiring that individual banks be maintained in a sound and viable condition, indicated that this was an important supervisory objective. For example, in acting upon membership applications, the Act required that the financial condition and the general character of the applying bank's management be considered.

Following the great depression and the rash of bank failures in the early 1930 s the Govemment began to take greater responsibility for the maintenance of strong, viable banks. Bank failure was associated with economic instability and the view developed that banks cannot be allowed to fail for so-called public interest reasons. This view led to the onerous bank regulations in the banking acts of 1933 and 1935 which sustain modern bank supervision. Thereafter, banking activities, rather than the quantity and quality of money, consistently received the major focus of bank regulation.

The control of bank assets and the maintenance of sound banks has become a paramount superisory objective. For example, belore admitting banks to the Federal Deposit Insurance Comporation (FDIC), their future eamings prospects, adequacy of capital, and character of management, as well as the convenience and needs of the community, must be considered. The Comptroller considers the same factors before granting charters, thus, in effect, giving the Federal Government power to limit the number of banking firms.

The Acts require that each Federal Reserve Bank ascertain whether bank credit is being used for purposes inconsistent with "sound credit conditions". If such macceptable use is made of bank credit, the Federal Reserve Board may suspend a member bank from the use of the credit facilities of the System.

These Acts placed increased restrictions on the establishment and operation of branches. The payment of interest on demand deposits was prohibited and maximum rates were set on time and savings deposits by the supervisory agencies. The Acts set limits to the bank's investments in its premises, divorced banking from security dealing, and set restrictions on loans to banking affliates, dividends payable, and bank capital. The Federal Reserve Board and the Comptroller of the Currency were authorized to remove bank officials for illegal or unsound bank practices. This legislation, in effect, limited the bank managerial function to those actions consistent with the regulators view that banks should always remain in condition to withstand another great depression. Furthernore, bank legislation and regulation by individual states during this period was often more restrictive than at the Federal level.

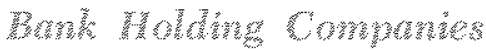

Until recently bank holding companies were subject to relatively few restrictions. State banking officials have generally found it diffoult to gain much control over such companies.

The first Federal regulation of bank holding companies occurred with the Banking Act of 1933. This Act provided the Federal Reserve Board with some control over the voting of member bank stock owned 
by corporations. It required such corporations to establish certain reserves, to publish financial statements, and to withdraw from the securities business.

Following the rapid growth of bank holding conpanies after World War II, Congress enacted the Bank Holding Company Act of 1956. This law restricted multiple bank holding company activities to banking and closely related services, and, with minor exceptions, forced them to divest themselves of ownership or control of any other kind of business. It limited most acquisitions of bank stock by such companies to the state in which their operations were principally conducted, thereby effectively curbing new interstate bank acquisitions. The Act was amended in 1966 so as to require prior approval of the Federal Reserve Board for future acquisitions by bank holding companies.

One-bank holding companies, however, were subject to less Federal control, and their number almost doubled from 1968 to 1970 . As a consequence of this rapid growth, some bankers, the regulators, and others who were fearful of these new competitors-called for their regulation. The Bank Holding Company Amendments of 1970 were passed, ending the exemption of one-bank holding companies from Federal control. The Amendments did, however, liberalize the activities in which bank holding companies could participate. They were permitted to acquire nonbank firms across state lines.

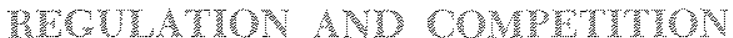

As a consequence of the onerous restrictions on banking and bank holding companies, the guality and efficiency of financial services have declined, and the competitiveness of the banking system has been reduced. As pointed out by the Hunt Commission, the interest rate regulations during the period of "tight" money in 1970 made it increasingly difficult for bank supervisors to accomplish their objectives of maintaining strong, viable firms, and at the same time decreased the role and effectiveness of the institutions they aimed to preserve. The regulations which prohibited banks from paying a market rate of interest to savers actually weakened the banks as savings were withdrawn and placed in higher-yielding investments. More importantly, however, savers, borrowers, and consumers were bearing unnecessary risks and costs.

In contrast to the controls on banks and bank holding companies, nonbanking firms enjoy rights of entry and flexibility in the introduction of new financial products and services not enjoyed by either banks or bank holking companies. Furthermore, as pointed out in a recent study by the First National City Bank, New York, some of these nonbank firms are relatively large credit suppliers. Three nonbank installment lenders have receivables outstanding equal to 11 percent of the total held by all commercial banks, and one has more receivables than the combined total for all commercial banks in New York and Chicago. It is not my intention to criticize these firms, but only to sug. gest that they saw business opportunities and entered the financial services market to the advantage of both the firm and the consumer.

In my view the public is entited to the best and lowest cost mancial service that the market can provide. Competition in providing such service is the best means of achieving this objective, but not all bankers are eager to participate in a freely competitive market. Some, probably rellecting their overly protected status, have not always been awake to their opportunites and challenges. They are not unanimous in their support of the Administration's efforts to remove some of the regulatory shackles to vigorous competitive operations. They are often blind to a competitor when it is called by some name other than a bank. But the very fact that nonbank competitors, such as the Farm Credit Banks, sales fnance companies, savings and loan associations, and the credit departments of retail stores, have entered the finance business and achieved vigorous growth indicates that commercial banks have left voids in the financial services rnaket. The assets of these nonbank financial firms increased more than ten-fold from 1946 to 1972 , and their share of the total financial services market rose from 43 to 62 percent.

The Hunt Commission recognized the excessive regulation of banks, and proposed changes that would free them from many controls. Its proposals included: the relaxation of interest rate restrictions, the removal of most usury ceilings on loans, the removal of limitations on branch banking, and the relaxation of chartering and investment restrictions. The Commission recognized that the public would be better served by the increased competition resulting from the implementation of the proposals. I am not here to promote any specific plan for restructuring the financial system, but rather to point out the economic forces facing the bank holding company movement. With this background, I believe those forces are now obvious. 


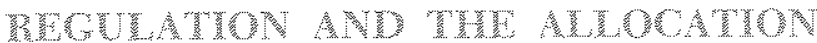

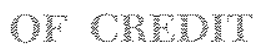

The demand for financial services is growing, and bank holding companies have the organization and the technical know-how to supply them. Competitive challenges abound which they are inhibited from meeting. However, if history is a reliable teacher they will have to fight for the opportunity to participate in such markets as an equal. Their opponents in the struggle for an equal opportunity to participate can be classified into two groups. First are those politically powerful sectors of the economy that demand preferred treatment in the credit allocation process. Second are the regulators of financial firms and their supporters, who include those current participants in the markets who fear competition. And third is a large segment of the population which believes that strong, viable financial firms can be maintained only by restricting their natural incentive to compete.

Much of the impetus for preferential treatment in the allocation of credit has occurred during periods of economic depressions or high nominal interest rates. When market rates exceed limits established by usury laws and Regulation $Q$, credit flows are diverted from normal patterns. These market baniers have tended to starve some sectors.

Numerous Govemment credit subsidy programs have been established to "correct" these assuned defects in the credit market and the number of such programs continues to grow. A staff study by the Joint Economic Committee of the Congress in 1972 listed 42 major Federal credit subsidy programs (those with outstanding credit of more than $\$ 10$ million). These programs, designed to finance agriculture, education, housing, commerce, economic development, natural resources, and medical care, cost the taxpayers of the nation $\$ 4.2$ billion in 1970 . At the close of 1972 direct government loans outstanding through these programs were estimated to be $\$ 56$ billion and the guaranteed loans $\$ 67$ billion. In addition to these 42 major programs, there are vumerous subsidized credit programs with less than $\$ 10$ million credit outstanding.

These programs provide preferred treatment for some activities at the expense of others since the total volume of credit avalable is not increased much, if any. They divert credit flows from more productive uses to those uses selected through the political process. They neither add to national well-being nor the well-being of most of those sectors that they purport to help. To the extent that they are successful in increasing credit flows into one sector, they cause excesses of resources in that sector relative to other sectors. If welfare of the individual is their objective, such welfare can be purchased at a much lower cost through cash grants. Furthermore, such programs are extremely biased against those individuals who have already obtamed their credit or other resources at market prices.

Of greater concern to bankers, however, should be the encroachment of such activities in the financial narkets. These programs are based on the false premise that our financial system is doing a poor job of allocating credit. Yet, instead of pointing out the efficiency of the free market system, and demanding equal opportunities to markets, bankers have often stood idly by or even assisted in the proliferation of credit markets by these privileged agencies. Indeed, the American Bankers Association actmally joined other groups this summer in urging Congress to enact legislation for a new program of guaranteed loans to livestock producers. By acceding to requests for subsidized credit, or assisting in furthering such activities, bankers may have contributed to the public view that something is wrong with our private credit allocation system.

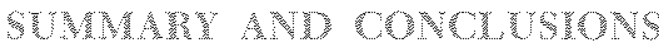

In summation bankers should not remain silent on such important subjects as political credit allocation and bank regulation. Most bankers know that the alleged problems are usually not credit problems at all, but only the voice of a social idealist. The alleged credit problem in the cattle feeding industry which led to the recent government credit program was actually a profit problem that the market system will solve. Once price relationships move to profitable levels, sufficient credit will be avalable to finance the feeders. The problem is simply made worse if additional credit is made available to ineficient producers diring periods of unfaworable price relationships. Bankers should speak out and resist useless government encroachment in this, as well as in other areas, including the various alleged consumer protection plans. Bankers have sat silent too long and let other less qualified people run their business, reduce their markets, and subsidize competitors with their profits.

In the regulatory area confusion still prevails as to which banking functions should be controlled. Hence, the urge to protect your firms from so-called "cutthroat" competiton is great. It arises from both current participants in the markets who fear your comm petition, from the desire of regulators to regulate, and from a large sector of the population which be- 
lieves that strong, "viable" francial frms necessary for" economic stability can only be maintained by re stricting their naturat incentive to compete. They associate falure of banks with economic depression. 基 my view it is the money-creating function of banks that has led to economic instability. We can protect the money holders throtgh deposit insurance and if we provide for a stable rate of monetary growth, the coonomy will function satisfactorily.

羔 do not view an occasional bank failure as being disastrous. An occasiona failure eliminates the ineffim cient and is a signal to other firms to exercise caution. Relatively free entry and exit are indicators that an industry is competitive. Regulation that is sufficiont to prevent new frms from entering and prevent failure is suffcient to inhibit growtit and vitalty in a competitive economy. The proposals for fimiting the rates payable on bank holding company credt instruments are examples of a regulation that will inhibit your growth. Jow success in avoiding such controls will thus likely determine your long-run growh and proftability.

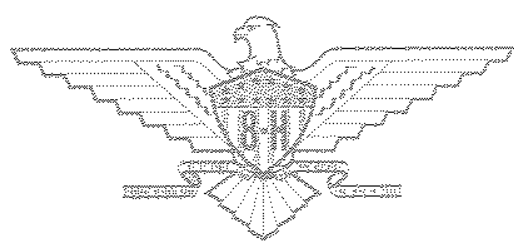

